\title{
Philosophy and Pluralism
}

\author{
Edited by David Archard
}

\author{
ROYAL INSTITUTE OF PHILOSOPHY \\ SUPPLEMENT: 40
}

We inhabit a world of differences-cultural, religious, moral, philosophical. The question that preoccupies the contributors to this volume is whether the fact of difference-plurality-inevitably leads to the conclusion that there cannot be a single truth, even in moral matters.

As befits a volume on pluralism, it brings together a wide variety of contributors with different backgrounds and distinctive skills and attitudes. The implications of plurality are examined with regard to religion, morality and philosophy itself, but the essays range widely to consider how we should respond at the social and political levels to the facts of plurality and the claims of the pluralist. No reader will be left in any doubt that the debate about pluralism raises questions that are fundamental not only for philosophical argumentation but for society at large.

\section{Contributors}

Catherine Audard, Harry Bunting, J. D. G. Evans, Keith Graham, Attracta Ingram,

C. J. McKnight, Susan Mendus, Tariq Modood, Alan Montefiore, Dermot Moran, Terry O'Keeffe, Bhikhu Parekh, Anthony Skillen, John Skorupski 